\title{
Re-examination of growth estimates in oceanic squids: the case of Kondakovia longimana (Onychoteuthidae) ${ }^{1}$
}

\author{
A. Jarre², M. R. Clarke, and D. Pauly
}

Jarre, A., Clarke, M. R., and Pauly, D. 1991. Re-examination of growth estimates in oceanic squids: the case of Kondakovia longimana (Onychoteuthidae). - ICES J. mar. Sci., 48: 195-200.

Earlier work by the second author on the growth of oceanic squids, based on sizefrequency distributions of beaks sampled from sperm whale stomachs and on structural marks on those beaks, showed that these squids apparently had growth rates far in excess of those reported for the fastest-growing fishes, e.g. bluefin tuna. The application of recently developed methods for analysis of length-frequency distributions to some of these earlier data, and new approaches for assessing and comparing the growth performance of fish and aquatic invertebrates, suggest the need for a downward revision of these high growth estimates. This is illustrated here with data on Kondakovia longimana (Cephalopoda, Onychoteuthidae) sampled off Durban and Donkergat, South Africa, in the early to mid-1960s.

A. Jarre, International Centre for Living Aquatic Resources Management (ICLARM) MC, P.O. Box 1501, Makati, Metro Manila, Philippines. ${ }^{2}$ M. R. Clarke, Ridge Court, Court Road, Newton Ferrers, Plymouth PL8 1DD, UK. D. Pauly, International Center for Living Aquatic Resources Management (ICLARM) MC, P.O. Box 1501, Makati, Metro Manila, Philippines.

\section{Introduction}

It has been often stated by marine biologists working on squids that their various adaptations make them very

${ }^{1}$ ICLARM Contribution No. 562.

${ }^{2}$ Present address: Alfred Wegener Institute for Polar and Marine Research, Columbusstraße, D-2850 Bremerhaven, Germany. fast-growing animals, more so than fishes (O'Dor et al., 1980; Erhardt et al., 1983; Lee et al., 1989). In this paper earlier estimates of growth in Kondakovia longimana (Onychoteuthidae) are reassessed, using recently developed methods for the estimation of growth from sizefrequency data and for the comparison of growth performance across taxa. This reassessment is intended to

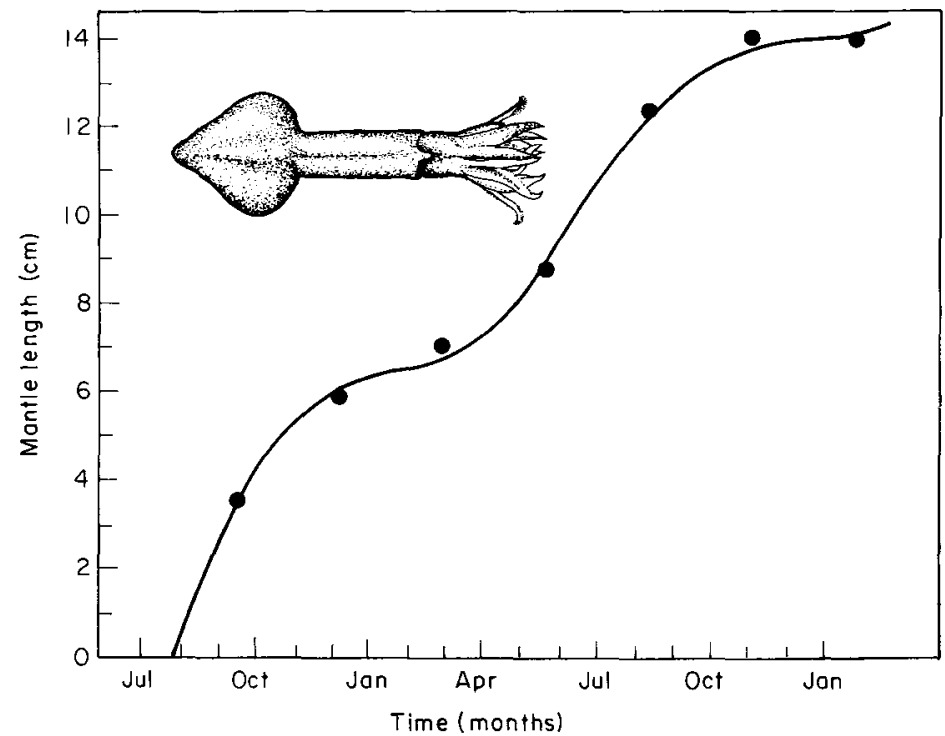

Figure 1. Seasonally oscillating growth curve for Loligo opalescens sampled at the Monterey Market, California, as obtained by fitting Equation (1) to size-at-age data of Spratt (1978, Fig. 1). $\mathrm{ML}_{\mathrm{x}}=20.8 \mathrm{~cm}, \mathrm{~K}=0.755 \mathrm{yr}^{-1}, \mathrm{C}=0.85$, WP $=0.08$ year. (see Table 3 for data sources). 
Table 1. Frequency distribution of lower beak length $(\mathbf{M L}=$ class midpoints, in $\mathrm{cm}$ ) of Kondakovia longimana collected from sperm whale stomachs in Durban (1962-1964) and Donkergat (19621963). (Data from Clarke, 1980, grouped by months, irrespective of year.)

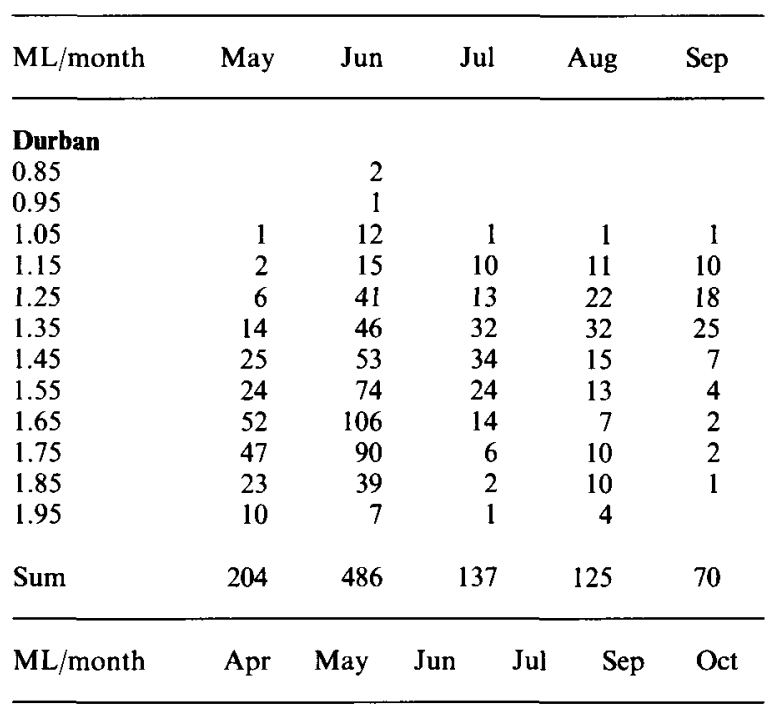

\begin{tabular}{lrrrrrr}
\hline $\begin{array}{l}\text { Donkergat } \\
1.05\end{array}$ & 1 & 3 & & 2 & & \\
1.15 & 1 & 0 & & 3 & & \\
1.25 & 4 & 9 & 2 & 11 & 3 & 8 \\
1.35 & 8 & 24 & 7 & 25 & 1 & 5 \\
1.45 & 20 & 39 & 10 & 46 & 2 & 10 \\
1.55 & 13 & 74 & 11 & 30 & 3 & 6 \\
1.65 & 10 & 75 & 33 & 21 & 1 & 5 \\
1.75 & 6 & 64 & 27 & 9 & 0 & 4 \\
1.85 & 3 & 34 & 10 & 4 & 1 & 2 \\
Sum & 66 & 322 & 100 & 151 & 11 & 40 \\
\hline
\end{tabular}

Table 2. Relationship between number of apparent growth bands on beaks of Kondakovia longimana and the mean wall lengths of these beaks (from Clarke, 1980).

\begin{tabular}{lcc}
\hline Band & $\begin{array}{c}\text { Mean wall length } \\
\text { of beaks at end } \\
\text { of growth period } \\
\text { no. }\end{array}$ & $\begin{array}{c}\text { No. of beaks } \\
\text { in sample }\end{array}$ \\
\hline & & \\
1 & 0.49 & 150 \\
2 & 0.83 & 150 \\
3 & 1.13 & 148 \\
4 & 1.34 & 131 \\
5 & 1.51 & 112 \\
6 & 1.67 & 93 \\
7 & 1.81 & 83 \\
8 & 1.92 & 60 \\
9 & 2.02 & 41 \\
10 & 2.08 & 22 \\
11 & 2.23 & 11 \\
12 & 2.06 & 6 \\
\hline
\end{tabular}

establish not only a range of "possible" growth parameters for $K$. longimana, but also for other - as yet unstudied squid species. Further, we shall suggest that squids do not grow faster than fishes of the family Scombridae (i.e. the mackerels and tunas), which have the fastest growth among fishes.

This contribution builds on an earlier paper (Pauly, 1985 ) in which evidence was presented showing that the growth of squids, like that of fishes, oscillates seasonally and that the growth models used to fit size-at-age data of squids should take this explicitly into account (see also Fig. 1).

\section{Material and methods}

\section{Estimation of growth parameters}

The seasonally oscillating growth model used here was developed independently by Hoenig and Choudary Hanumara (1982) and Somers (1988) and has the form:

$\mathrm{L}_{\mathbf{t}}=\mathrm{L}_{\infty}{ }^{*}\left(1-\exp \left(-\mathrm{K}^{*}\left(\mathrm{t}-\mathrm{t}_{0}\right)-\mathrm{S}_{1}+\mathrm{S}_{2}\right)\right)$

where

$\mathrm{S}_{1}=\mathrm{C}^{*} \mathrm{~K} /\left(2^{*} \pi\right)^{*} \sin \left(\mathrm{t}-\mathrm{t}_{0}\right)$

$\mathrm{S}_{2}=\mathrm{C}^{*} \mathrm{~K} /\left(2^{*} \pi\right)^{*} \sin \left(\mathrm{t}_{0}-\mathrm{t}_{\mathrm{s}}\right)$

and $\mathbf{L}_{\mathbf{t}}=$ length at time $t, \mathrm{~L}_{\infty}=$ asymptotic length, $\mathrm{K}=$ growth parameter of dimension time ${ }^{-1}, \mathrm{t}=$ time (age; in year), $t_{0}=$ "age" at length $0, t_{s}=$ starting-point of oscillations with respect to $t_{0}=0, C=$ parameter expressing the amplitude of the oscillations. (Note that for fitting purposes, $t_{s}$ is replaced by a "Winter Point", i.e. the period of the year when growth is lowest; $W P=t_{s}+0.5$ ).

This seasonally oscillating growth curve is constructed such that the growth parameter $\mathrm{K}$ is directly comparable to the growth parameter of the non-seasonal von Bertalanffy growth equation (a non-seasonal growth equation, fitted (but necessarily less well) to the data in Figure 1 by means of a von Bertalanffy plot, yielded an estimate of $\mathrm{K}=0.79 \mathrm{yr}^{-1}$ ).

Equation (1) was fitted to size-frequency distributions of lower beaks of K. longimana from Clarke (1980), derived from sperm whale stomachs sampled at Durban and Donkergat, South Africa, in 1962-1964 and 19621963, respectively (Table 1 ). The fitting was carried out using a non-parametric method, the ELEFAN I program of Pauly and David (1981), as implemented by Gayanilo et al. (1988).

However, because of the variability of the data in question (see below), the size frequencies in Table l could not be used to estimate all parameters of Equation (1). Instead, plausible values of the parameters $\mathrm{L}_{\infty}, \mathrm{C}$, and WP were postulated, and the goodness-of-fit index of the ELEFAN I program ( $\mathrm{Rn}$, roughly analogous to the coefficient of determination or $\mathrm{r}^{2}$ of parametric methods) 


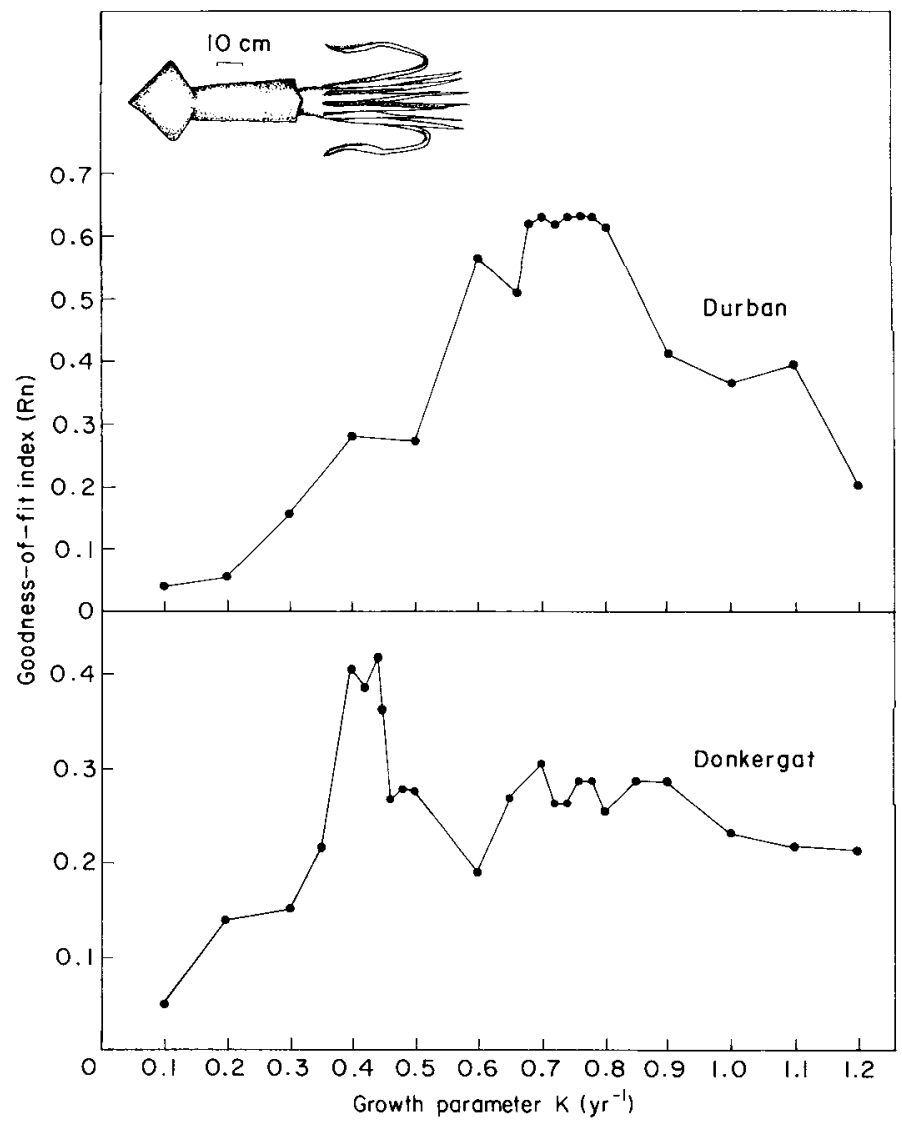

Figure 2. Plots of the goodness-of-fit index of the ELEFAN I program $\left(R_{n}=10^{\mathrm{ESP} / A S P} / 10\right)$ vs. input values of $K$, from $L_{\infty}=2, C=0.4$, and $\mathbf{W P}=0.7$.

was computed for different values of $K$. This last parameter is crucial, as it determines how fast $\mathrm{L}_{\infty}$ is approached and hence also correlates, in fishes with natural mortality and longevity (Pauly, 1980).

The maximum reported lower beak length of $2.1 \mathrm{~cm}$, corresponding to a mantle length of $87 \mathrm{~cm}$ (Clarke, 1980), was used as estimate of asymptotic length. Conversion of length to weight was performed using: .

$\log _{10} \mathrm{~W}=2.78+5.24 \log _{10} \mathrm{LRL}$

where $\mathrm{W}$ is the body wet weight (in $\mathrm{g}$ ), and LRL the rostral length of the lower beak (in cm) (Clarke, 1980).

The postulated value of $\mathrm{C}=0.4$ was estimated from the empirical relationship between $\mathrm{C}$ in fishes and aquatic invertebrates and the summer-winter temperature difference of their habitat (Longhurst and Pauly, 1987). Finally, the external estimate of WP was set at 0.7 year, the coldest period in (southern) winter.

In addition to the lower beak length frequencies, a von Bertalanffy growth curve (without seasonality), i.e.

$L_{t}=L_{x}\left(1-\exp \left(-K^{*}\left(t-t_{0}\right)\right)\right)$ was fitted to growth data obtained by Clarke (1965, ${ }^{1}$ 1980, and see Table 2) from the distance between cyclic growth structures on the beaks (similar to those on fish otoliths; for details on measurement see Clarke, 1965).

\section{Comparisons of growth performance}

For purely statistical reasons, different estimates of asymptotic size for equations such as (1) or (3) will tend, to some extent, to be inversely correlated with the corresponding estimates of the parameter $\mathrm{K}$. However, more than just a statistical artefact is involved; organisms with high asymptotic sizes tend to have low values of $K$, whatever the fitting method. When corresponding pairs of $\mathrm{L}_{\infty}$ and $K$ values, or better of $W_{\infty}$ (the weight corresponding to $\mathrm{L}_{\infty}$ ) and $\mathrm{K}$ values, are plotted on double logarithmic paper, this results in the growth parameters of related organisms forming ellipsoid scatterplots which show low variability

${ }^{1}$ The specimens used by Clarke (1965) were later reidentified as Kondakovia longimana (Clarke, 1980). 
Table 3. Growth parameters of squids, as used to infer their position on an auximetric grid (see also Fig. 3).

\begin{tabular}{|c|c|c|c|c|c|}
\hline Species & Area & $\mathrm{L}_{x}(\mathrm{~cm})$ & $\mathbf{W}_{\infty}(\mathrm{g})$ & $\mathrm{K}\left(\mathrm{yr}^{-1}\right)$ & Source \\
\hline $\begin{array}{l}1 \text { Todarodes pacificus } \\
\text { (fem.) }\end{array}$ & Northwest Pacific & 28.1 & 461 & 0.24 & Okutani (1983) \\
\hline $\begin{array}{l}2 \text { Todarodes pacificus } \\
\text { (male) }\end{array}$ & Northwest Pacific & 25.8 & 349 & 0.28 & Okutani (1983) \\
\hline 3 Loligo gahi & Southern Chile & 37.0 & 410 & 0.34 & Arancibia and Robotham (1984) \\
\hline 4 Loligo opalescens & California & 20.8 & 125 & 0.76 & $\begin{array}{l}\text { Fig. 1, based on Spratt (1978) and } \\
\text { Fields (1965) }\end{array}$ \\
\hline 5 Loligo pealei & Gulf of Mexico & 23.0 & 207 & 0.95 & $\begin{array}{l}\text { Pauly (1965), partly based on } \\
\text { Lange and Johnson (1981) }\end{array}$ \\
\hline 6 Loligo pealei & Off New Zealand & 38.3 & 680 & 0.59 & $\begin{array}{l}\text { Pauly (1965), based on Ikeda and } \\
\text { Nagasaki (MS, 1975), and Lange } \\
\text { and Johnson (1981) }\end{array}$ \\
\hline 7 Loligo chinensis & Gulf of Thailand & 40.9 & 704 & 0.49 & Supongpan (1988) \\
\hline 8 Loligo duvauceli & Gulf of Thailand & 26.6 & 265 & 0.84 & Supongpan (1988) \\
\hline 9 Sepioteuthis lessoniana & Southern India & 27.0 & 650 & 0.73 & Longhurst and Pauly (1987) \\
\hline $\begin{array}{l}10 \text { Onychoteuthis boreali } \\
\text { japonica }\end{array}$ & East of Hokkaido & 40.0 & 1575 & 0.47 & $\begin{array}{l}\text { Pauly (1985), based on Okutani } \\
\text { and Murata (1983) }\end{array}$ \\
\hline $\begin{array}{l}11 \begin{array}{l}\text { O. boreali japonica } \\
\text { (male) }\end{array} \\
\text { (male }\end{array}$ & East of Hokkaido & 35.0 & 1600 & 0.48 & $\begin{array}{l}\text { Pauly (1985), based on Okutani } \\
\text { and Murata (1983) }\end{array}$ \\
\hline $\begin{array}{l}12 \text { Illex illecebrosus } \\
\text { (fem.) }\end{array}$ & Off Eastern Canada & 29.4 & 500 & 0.65 & $\begin{array}{l}\text { Pauly (1985), based on Lange and } \\
\text { Sissenwine (1983) }\end{array}$ \\
\hline $\begin{array}{l}13 \text { Illex illecebrosus } \\
\text { (male) }\end{array}$ & Off Eastern Canada & 23.9 & 290 & 1.08 & $\begin{array}{l}\text { Pauly (1985), based on Lange and } \\
\text { Sissenwine (1983) }\end{array}$ \\
\hline 14 Illex illecebrosus & Northwest Atlantic & 32.0 & 600 & 2.50 & $\begin{array}{l}\text { Pauly (1985), based on Au (MS, } \\
\text { 1975) and Lange and Johnson } \\
\text { (1981) }\end{array}$ \\
\hline $\begin{array}{l}15 \text { Loligo duvauceli } \\
\text { (fem.) }\end{array}$ & Southern India & 23.8 & 276 & 1.70 & Meiyappan and Srinath (1989) \\
\hline 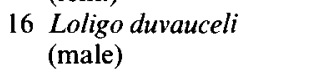 & Southern India & 37.2 & 590 & 1.10 & Meiyappan and Srinath (1989) \\
\hline 17 Dosidicus gigas & Gulf of California & 96.0 & 22000 & 1.20 & $\begin{array}{l}\text { Pauly (1985), based on Erhardt } e t \\
\text { al. (1983) }\end{array}$ \\
\hline 18 Kondakovia longimana & Antarctica & 85.2 & 29400 & $0.44(?)$ & $\begin{array}{l}\text { This paper, based on Clarke (1980); } \\
\text { See text. }\end{array}$ \\
\hline
\end{tabular}

and define the growth performance of the taxon to which the organisms belong (Pauly, 1979; Longhurst and Pauly, 1987).

\section{Results}

Figure 2 shows plots of the goodness-of-fit index Rn vs. K for $K$. longimana with the parameters $\mathrm{L}_{x}=2.1 \mathrm{~cm}, \mathrm{C}=0.4$, and $W P=0.7$ year. Figure $2 a$ shows that, for the data collected at Durban, a maximum of Rn was obtained with $\mathrm{K}=0.8 \mathrm{yr}^{-1}$. For the data collected at Donkergat (Fig. 2B), a maximum was obtained at $\mathrm{K}=0.4 \mathrm{yr}^{-1}$. Combining the two data sets led to similar results, i.e. it was not possible to determine unambiguously the growth coefficient $\mathrm{K}$ from these data.

The von Bertalanffy curve fitted to the beak growth structures data of Table 2 yielded an extremely good fit. As the relation between growth bands and absolute age is unknown, time increments of 3, 4, and 6 months were considered as growth period between the bands, resulting in estimates of $\mathrm{K}=0.8 \mathrm{yr}^{-1}, 0.6 \mathrm{yr}^{-1}$, and $0.4 \mathrm{yr}^{-1}$, respectively, and covering the above range of $K$ values. The estimated asymptotic beak length was $2.34 \mathrm{~cm}$ in all three cases, corresponding to an asymptotic dorsal mantle length of $98 \mathrm{~cm}$.

Table 3 presents our compilation of growth parameters for squids, most of which derive from analysis of modal progression in length frequencies and for which the problem of aging does not therefore arise. Figure 3 presents the auximetric grid that forms, along with the above results, the basis of our discussion.

\section{Discussion}

Figure 3 suggests that squids generally have a growth performance similar to that of the slower-growing species among the scombrids. There is also some indication that some groups (e.g. Todarodes, see nos. 1 and 2 in Fig. 3) may have a lower growth performance, comparable to that of clupeids.

Some extremely high growth performances, such as reported for Illex illecebrosus by Amaratunga (1980), may 


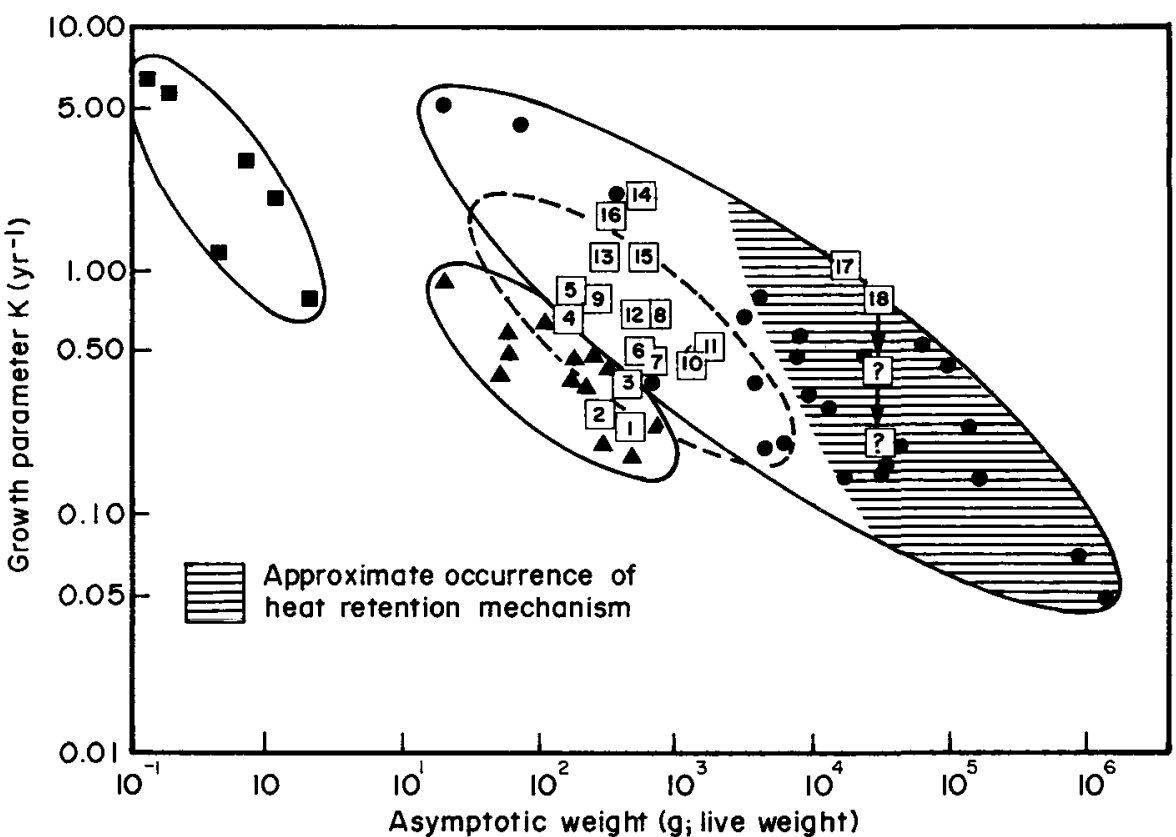

Figure 3. Auximetric grid showing ellipsoids for Cyprinidontidae (= guppies), Clupeidae (herring and sardine), Scombridae (mackerel and tunas) and various squids (from Table 3 ). The shading indicates the area where metabolic rate is so high that the scombrid species in question maintain a temperature higher than that of the environment (shaded area adapted from Table 1 in Carey et al., 1971). $\mathbf{\square}=$ Cyprinidontidae, $\Delta=$ Clupeidae, $\boldsymbol{\Theta}=$ Scombridae, $\square=$ Various squids

probably be incorrect, given that other well-documented estimates exist for the same species which match those of other squid species of the same size range (see Table 3 and Fig. 3, nos. 12, 13, 14). The information given by Lee $e t$ al. (1989) for Sepioteuthis lessionana raised in captivity does not allow for estimation of growth parameters, hence this species could not be included in our comparisons.

The extremely high growth rate reported by Erhardt et al. (1983) for Dosidicus gigas (no. 17 in Table 3 and Fig. 3) may also be questionable: it implies a metabolic rate far in excess of that reported from the most advanced scombrids. The high metabolic rate of these scombrids has led to numerous anatomical adaptations, especially the complex counter-current systems that have evolved to retain such heat (see Carey et al., 1971 and contributions in Sharp and Dizon, 1978). To date, such adaptations have not been reported from even the most active and largest squids, which argues against their having a metabolic rate as high as or even higher than those of large scombrids.

This brings us back to $K$. longimana. The above bioenergetic considerations suggest that the growth parameters estimated from a curve between " $C$ and $D$ " in Figure 75 of Clarke (1980), i.e. with a three months' interval between the growth bands and, correspondingly, with $\mathrm{K} \geq 0.8 \mathrm{yr}^{-1}$ (on or above square 18 in Fig. 3), are too high. Such fast growth would also not be supported by the plots in Figure 2a or $2 \mathrm{~b}$. In Figure 3 the square directly below square no. 18 shows the position which Kondakovia longimana would take on the auximetric grid if the peak at $\mathrm{K}=0.4 \mathrm{yr}^{-1}$ in Figure $2 \mathrm{~b}$ was accepted. We believe that this $\mathrm{K}$ value is still too high, but cannot demonstrate this because the data of Table 1 lack the small, fast-growing animals from which reliable estimates of $K$ could be obtained and hence growth rate safely inferred. Accepting $\mathrm{K}=0.4 \mathrm{yr}^{-1}$, which implies that the growth structures in Table 2 would be 0.5 year apart, implies in any case a longevity of at least $4-5$ years, which is $2-3$ times that assumed earlier.

Ecological reasoning, taking into consideration the strong annual pulse in Antarctic waters, might even indicate a 12 months' period for those growth bands, further reducing $\mathrm{K}$ (to $0.2 \mathrm{yr}^{-1}$, Fig. 3) and increasing longevity to 8-10 years, as also briefly discussed by Clarke (1965). These considerations strongly suggest the need for new studies on the growth of large cephalopods, through which their true age and related vital statistics (e.g. mortality, production/biomass ratio, etc.) could be established.

\section{References}

Amaratunga, T. 1980. Growth and maturation patterns of the short-finned squid (Illex illecebrosus) on the Scotian shelf. NAFO SCR Doc. No. 30, Ser., 62, 17 pp.

Arancibia, H., and Robotham, H. 1984. Crecimiento y edad del calamar (Loligo gahi Orbigny) del la region austral de Chile. Invest. Pesq., 31: 71-79. 
Au, D. W. K. 1975. Considerations of squid (Loligo and Illex) population dynamics and recommendations for rational exploitation. MS, ICNAF Res. Doc. No. 61, Ser., 3543 13 pp.

Carey, F. G., Teal, J. M., Kanwisher, J. W., and Lawson, K. D. 1971. Warm-bodied fish. Am. Zool., 11: 137-145.

Clarke, M. R. 1965. "Growth rings" in the beaks of the squid Moroteuthis ingens (Oegopsida: Onychoteuthidae) Malacologia, 3(2): 287-307.

Clarke, M. R. 1980. Cephalopods in the diet of sperm whales of the southern hemisphere and their bearing on sperm whale biology. Discovery Rep., (37). 324 pp.

Erhardt, N. M., Jaquemin, P. S., Garcia, F., Gonzalez, G. G., Lopez, J. M., Ortiz, B., and Solis, A. 1983. On the fishery and biology of the giant squid Dosidicus gigas in the Gulf of California, Mexico. In Advances in assessment of world cephalopod resources, pp. 306-340. Ed. by J. F. Caddy. FAO Fish. Tech. Pap., 231. 452 pp.

Fields, W. G. 1965. The structure, development, food relations, reproduction and life history of the squid Loligo opalescens Berry. Fish. Bull. Calif. Dept. Fish Game, 131: 1-108.

Gayanilo, F. C., Jr, Soriano, M., and Pauly, D. 1988. A draft guide to the Compleat ELEFAN. ICLARM Software 2, 65 pp. International Center for Living Aquatic Resources Management, Manila, Philippines.

Hoenig, N., and Choudary Hanumara, R. 1982. A statistical study of seasonal growth models for fishes. Tech. Rep. Dept Comp. Sci. Stat., University of Rhode Island, Kingston, USA

Ikeda, I., and Nagasaki, F. 1975. Stock assessment of Loligo in ICNAF subarea 5 and statistical area 6 . MS., ICNAF Res. Doc. No. 44, Ser. No. 3523, 5 pp.

Lange, A. M. T., and Johnson, K. L. 1981. Dorsal mantle lengthtotal weight relationship of squids Loligo pealei and Illex illecebrosus from the Atlantic coast of the United States. NOAA Tech. Rep. NMFS Circ., 745, 17 pp.

Lange, A. M. T., and Sissenwine, M. P. 1983. Squid resources of the Northwest Atlantic. In Advances and assessment of world cephalopod resources, pp. 21-54. Ed. by J. F. Caddy, FAO Fish. Tech. Pap., 231, 452 pp.

Lee, P. G., Hanlon, R. T., and Yang, W. T. 1989. Squid mariculture: first major success. In Vol. of Abstracts, p. 94. Aquaculture Meeting 1989, World Aquaculture Society, 12-16 February 1989, Los Angeles, USA.

Longhurst, A. R., and Pauly, D. 1987. Ecology of tropical oceans. Academic Press, San Diego, USA. 407 pp.

Meiyappan, M. M., and Srinath, M. 1989. Growth and mortality of the Indian squid (Loligo duvauceli) off Cochin, India. In Contributions to tropical fish stock assessment in India. Papers prepared by the participants at the FAO/DANIDA/ ICAR National Follow-up Training Course in Fish Stock Assessment, Cochin, India, from 2 to 28 November 1987, pp 1-14. Ed. by S. C. Venema and N. P. van Zalinge. Food and Agriculture Organisation of the United Nations, Rome. 157 pp.

Moreau, J., Bambino, C., and Pauly, D. 1986. A comparison of four indices of overall fish growth performance based on 100 tilapia populations (Fam. Cichlidae). In The first Asian fisheries forum, pp. 201-206. Ed. by J. L. Maclean, L. B. Dizon, and L. V. Hosillos. Asian Fisheries Society, Manila.

O'Dor, R. K., Durward, R. S., Vessey, E., and Amaratunga, T. 1980. Feeding and growth in captive squid, Illex illecebrosus, and the influence of food availability on growth in the natural population. ICNAF Sel. Papers, 6: 15-21

Okutani, T. 1983. Todarodes pacificus. In Cephalopod life cycles. Vol. I, Species accounts, pp. 201-214. Ed. by P. R. Boyle. Academic Press, London. 473 pp.

Okutani, T., and Murata, M. 1983. A review of the biology of the oceanic squid, Onychoteuthis borealojaponica. Mem. Nat. Mus. Vict., 44: 189-195.

Pauly, D. 1979. Gill size and temperature as governing factors in fish growth: a generalization of von Bertalanffy's growth formula. Ber. Inst. Meereskunde, Univ. Kiel, No. 63, $\mathrm{XV}+156 \mathrm{pp}$.

Pauly, D. 1980. On the interrelationships between natural mortality, growth parameters and mean environmental temperature in 175 fish stocks. J. Cons. int. Explor. Mer, 39(3): 175-192.

Pauly, D. 1985. Population dynamics of short-lived species, with emphasis on squids. NAFO Sci. Coun. Studies, 9: 143-154.

Pauly, D., and David, N. 1981. ELEFAN I, a BASIC program for the objective extraction of growth parameters from length-frequency data. Meeresforschung/Reports on Marine Research, 28(4): 205-211.

Roper, C. F. E., Sweeney, M. J., and Nauen, C. E. 1984 . Cephalopods of the world: an annotated and illustrated catalogue of species of interest to fisheries. FAO Fish. Synop. No. 125, Vol. 3. Rome. 277 pp.

Sharp, G. D., and Dizon, A. E. 1978. The physiological ecology of fishes. Academic Press, New York.

Somers, I. F. 1988. On a seasonally oscillation growth function. Fishbyte, 6(1): 8-11.

Spratt, J. F. 1978. Age and growth of the market squid, Loligo opalescens Berry, in Monterey Bay from statoliths. Fish. Bull. Calif. Dept. Fish Game, 169: 35 44.

Supongpan, M. 1988. Assessment of Indian squid (Loligo duvauceli) and mitre squid (L.chinensis) in the Gulf of Thailand. In Contributions to tropical fisheries biology, pp. 25-41. Ed. by S. Venema, J. M. Christensen and D. Pauly. Contributions prepared by the participants at the FAO/ DANIDA follow-up training courses on fish stock assessment in the tropics, Hirtshals, Denmark, 5-30 May 1986 and Manila, Philippines, 12 January to 6 February 1987. FAO Fish. Rep., 389. 519 pp. 